\title{
An Essay on Hittite Cultic Calendar Based Upon the Festivals
}

\author{
By Serkan Demirel
}

Due to the lack of adequate information, there is no an attempt to make a Hittite cultic calendar. But, festivals associated with the agricultural cycle for the Hittite cultic calendar can be taken into account. There were numerous festivals in Hittite Anatolia during the second millennium BC. While some of these festivals took more than one month, some were taking in a few hours. Typically, Hittite festivals have spiritual characteristics and consist of libations for different types of gods. It is possible to make a cultic calendar considering the distribution of festivals during the year. Most of the festivals are taking place in autumn and spring. Therefore, it may be said that Hittite festivals are connected with the agricultural cycle. The spring feats in the beginning of agricultural activities celebrated for the gods related to "seed" and the autumn feats in the end of the agricultural activities celebrated for the gods related to "harvest". This situation indicates that the Hittite cultic calendar has an economic aspect. The gods in the Hittite pantheon represent natural events that determine agricultural activities. For this reason it can be said that the agricultural cycle formed the Hittite cultic calendar.

Even though they were a major political power in the $2^{\text {nd }}$ Millennium BC Anatolia, Hittites remained under the influence of other societies in cultural terms. This influence can be clearly observed especially in religious aspects. Relating with the spiritual world of the Hittites, religious festivals, rituals and mythological tales bear evident traces of the Anatolian and other Near Eastern communities of Antiquity. It is also possible to monitor this influence on Greek and Roman cultures, after the period of the Hittites. ${ }^{1}$

Most Hittite cuneiform texts bear religious characteristics in nature. These texts mention the names of about one hundred seventy festivals ${ }^{2}$ and rituals. They were celebrated on a regular basis and this situation indicates the existence of a cultic calendar. In the current study, a dating effort will be made to find out the distribution of these religious events throughout the year.

Except for a few great festivals, most Hittite cuneiform texts only mention the names of the religious festivals and rituals. Even though the subject is disputed, it should not be forgotten that the term "festival" could be used in a different meaning- as opposed to present connotations- by Hittites, because the

\footnotetext{
* Assistant Professor, Department of Archaeology, Faculty of Art, Karadeniz Technical University, Turkey.

1. P. Walcot, Hesiod and the Near East (Cardiff: Wales U.P., 1966), 3ff; H. G. Guterbock, "The Hittite Version of the Hurrian Kumarbi Myths: Oriental Forerunners of Hesiod, Plate III," American Journal of Arhaeology, 52, no. 1 (1948): 123-134.

2. A. Unal, Hititler Devri Anadolu II [Anatolia in Hittite Age II] (Istanbul: Arkeoloji ve Sanat, 2003), 92.
} 
Sumerian monogram of EZEN, (Hittite reading šiyamana-? ${ }^{3}$ ) also means "cult meal" and "great feast". ${ }^{4}$ What was meant here must be the libation performed for gods. Therefore, excluding some grand religious festivals, it can be wiser to see these activities as some sort of rituals that include libations performed for the gods, rather than festivals in today's sense.

As it can be understood from the instruction texts relating the temple servitors, Hittites were quite precise about the timing of their religious ceremonies. ${ }^{5}$ Importance was not attached to this precise timing in vain, because a substantial number of these events were in parallel with the agricultural implementations taking place throughout the year.

It has been revealed that the most important festivals and rituals mentioned in Hittite texts were generally performed either in spring or fall. Rather than a mere coincidence, this must have been related with the transforming nature and agricultural cycle. The agricultural year starts in Anatolia in spring with planting seeds, and ends in fall with the harvesting of crops. In a similar tendency, festival rituals of the Hittites in spring were related with seed, soil and the New Year and the rituals in fall were related with harvesting and threshing. ${ }^{6}$ It may be possible to generate a Hittite cultic calendar based on the agricultural characteristics of the mentioned religious events.

We do not encounter any names of months in the Hittite cuneiform texts. Nevertheless, three seasons are mentioned, which are hamešhant (spring), zenant (fall), and gimant (winter). ${ }^{7}$ Connected with fall, there are also some marks $\left(B U R U_{X}\right)$ indicating summer. ${ }^{8}$ Although not yet certain, the Hittites are believed to have used a lunar based calendar. ${ }^{9}$ If it was so, months changed positions within the year independently of seasons.

3. A. Unal, Multilinguales HandwOrterbuch des Hethitischen, A Concise Multilingual Hittite Dictionary, Hitit Cok Dilli El SOzlügü (Hamburg: Verlag Dr. Kovac, Fachverlag für Wissenschaftliche Literatur, 2007), 120.

4. There are different interpretations about EZEN, for detailed information see A. A. Archi, "Das Kultmahl bei den Hethitern" ["The Cultic-Meal in the Hittites"] 8 Türk Tarih Kongresi, TTK Yayınları, (1979): 197ff; A. Unal, The Hittite Ritual of Hantitassu from the City of Hurma against Troublesome Years (Ankara: TTK Yayınlar1, 1996), 510ff. Furthermore for dusgarat- see O. S. Gavaz, Hitit Krallarının Kult Gezileri. Ayinler, Ziyaret Merkezleri, Yollar, Lokalizasyonla Ilgili Yeni Gozlemler [The Cultic-tour of Hittite Kings, Rituals, Visiting Centers, Roads, New Observation about the Localizations] (Corum: Corum Belediyesi Yayınlar1, 2012), 32ff.

${ }^{5}$ KUB 13.4 IX 57-61; A. Suel, Hitit Kaynaklarında Tapınak Gorevlileri ile Ilgili Bir Direktif Metni [An Instruction Text about the Temple Officiers in the Hittite Sources] (Ankara: Ankara Universitesi Dil ve Tarih Cografya Fakultesi Yayınları, 1985), 47-49.

6. V. Ardzinba, Eskicag Anadolu Ayinleri ve Mitleri [The Anatolian Rituals and Myths in the Ancient Age] (Ankara: Kafdav Y., 2010), $13 \mathrm{ff}$.

7. A. Goetze, "On the Hittite Words for 'Year' and the Seasons and for 'Night' and 'Day'", Language, 27, no. 4, (1951): 467-576.

8. H. A. Hoffner, Alimenta Hethaeorum, Food Production in Hittite Asia Minor (New Heaven: American Oriental Series 55 1974), 24.

9. $§ 17$ in Hittite Law: "[if] it is her tenth month" KBo 6.3 I 40-42; H. A. Hoffner, The Laws of the Hittites: a Critical Edition (Leiden, New York, Koln: Documenta et Monumenta Orientis Antiqui, 1997), 28. A normal period of pregnancy in a solar calendar lasts for 280 days and it corresponds to the 10th month in a lunar calendar. In this sense, months must have lasted about 28-29 days in the lunar-based Hittite calendar. G. S. Erginoz, "Hititlerde 
The strongest evidence about the beginning of the Hittite cultic calendar indicates that it was spring, because calendars started with religious rituals performed at the beginning of the agricultural season in most agriculture-based communities of the ancient Near East. The solar calendar of Egypt started with the month of Hoiach, when the Nile started to overflow in the middle of June. ${ }^{10}$ In the lunar calendars of the ancient Mesopotamia the year started with the festival of Akitu, which was celebrated in March-April. ${ }^{11}$ It can be assumed that a similar approach was adopted in Anatolia during the Hittites era. ${ }^{12}$ In such a case, spring, through which the agricultural season starts in Anatolia, can be perceived as the beginning point of the Hittite calendar/cultic calendar. Because Hittites were an agricultural society, and success or failure in agriculture were vital for them. To be able to get a hold of the fertility arising in spring, the major religious rituals were performed at that period of the year

The festival of purulli ( ${ }^{\text {EZEN }}$ purulli/wurulli/purulliyaš), which is mentioned in the Hittite cuneiform texts, could be indicating that the Hittite cultic calendar began in spring. It is understood from the Illuyanka myth ${ }^{13}$ and annals of Muršili II $^{14}$ which provide us with information about the festival, that the festival was celebrated in spring and at the beginning of the year. Although there is no information about the theme of the festival, the fact that the word

Astronomi Bilgisine ve Hitit Takvimine Bir Bakıs" ["An essay on the astronomical knowledge and the calendar of the Hittites"], Osmanl Bilimi Araştırmalart, 9, no. 1-2 (2008): 209. Another finding that indicates the Hittites must have used a lunar calendar is present in the Hittite texts providing detailed information about the Lunar Eclipse. In the relevant parts of these texts, it is uttered that the end of the old month (on the calendar) and the beginning of the new month were caused by the death of the Lunar God (lunar eclipse). KUB 8.1 IIII 8-10, 17 19; Hoffner, Alimenta Hethaeorum, 24, 25.

10. A. Sayıl1, Misirlilarda ve Mezopotamyalılarda Matematik, Astronomi ve Tip [Mathematics, Astronomy and Medicine in the Egyptians and Mesopotamians] (Ankara: Türk Tarih Kurumu Basımevi, 1966), 77; A. T. Okse, "Eski Onasya'dan Gunumuze Yeni Y1l Bayramları, Bereket ve Yagmur Yagdırma Torenleri" ["New Year Feasts, Fertility and Rain Making Ceremonies since the Early Near East"], Bilig, Ahmet Yesevi Universitesi Sosyal Bilimler Dergisi, 36 (2006): 53.

11. "March or April"; Sayıl1, Misırlılarda ve Mezopotamyalılarda Matematik, Astronomi ve Tip, 330. "probably spring equinox"; F. Rochberg, "Astronomy and Calendars in Ancient Mesopotamia", Civilizations of the Ancient Near East, 3, (2000): 1931. "April"; V. Haas, "Geschichte der Hethitischen Religion", Handbuch der Orientalistik, 15 (1994): 82, 83. For more information about Akitu Festival; A. K. Grayson, "Chronicles and the Akitu Festival," Rencontre Assyriologique Internationale, 17 (1970): 160-170.

12. The originality of the Hittite calendar is not clear. However, the fact that the astronomical texts were excavated in Hattusa archives were actually originated from Babylon indicates that the calendar used here was a lunar one. U. Koch-Westenholz, "Mesopotamian Astrology at Hattusa," Grazer Morgenlandische Studien, 3, Die Rolle der Astronomie in den Kulturen Mesopotamiens. Beitrage zum 3. Grazer Morgenländischen Symposium, 23-27. September 1991, (1993): 231-246.

13. "Let the land grow (and) thrive, and the land be secure and when it (indeed) grows (and) thrives, then they perform the festival of purulli", KBo 3.7 I 5-8; G. Beckman, "The Anatolian Myth of Illuyanka," Journal of Near Eastern Studies, 14 (1982): 12.

14. "When it becomes spring, I celebrated the purulliyas festival for Storm-God of Hatti and the Storm-God of Zippalanda," KBo 2.5 Ay. 38-40; A. Goetze, "Die Annalen des Mursilis" ["The Annals of Mursilis II"], Mitteilungen der Vorderasiatisch, Aegyptischen Gesellschaft, 38 (1933): 188. 
"pur/wur" ${ }^{15}$ means "country, land"16 and that it was performed at the beginning of the agricultural season may be referring to the agricultural aspect of the festival.

Another Hittite festival which is understood to have been celebrated in spring is the AN.TAH.ŠUM Plant Festival ( ${ }^{\mathrm{EZEN}}$ AN.TAH. $\left.\breve{S} U \mathrm{MM}^{\mathrm{SAR}}\right){ }^{17}$ The species of this plant is not definite. Different opinions have been put forward about it being a type of colchicum, ${ }^{18}$ saffron, ${ }^{19}$ or lily. ${ }^{20}$ However, the plant must have been grown in spring, when the festival was performed. ${ }^{21}$ The Texts mention the opening of the giant pithos (harši) during a ritual performed on the $\operatorname{sixth}^{22}$ and twelfth ${ }^{23}$ day of the festival, which lasted for thirty-eight days in total. The opening and closing of these pithos were performed through certain rituals. During the Festival of filling in the harši pithos ( ${ }^{\mathrm{EZNN}}$ haršs $i$ $[\check{s} u h h u w a s ̌])^{24}$ celebrated in fall immediately after harvesting, these grain pithos were filled with barley and then sealed. In the following spring, the sealed pithos were opened in the Festival of opening the harši pithos ( ${ }^{\text {EZEN DUG }}$ haršs $i$

15. CHD, Vol. P (Chicago: Oriental Institute, 1997), 392. purulliyas=wurulliyas; V. Haas, Die Hethitische Literatur: Texte, Stilistik, Motive [The Hittite Literature: Texts, Style, Motives] (Berlin: DEU, Walter de Gruyter, 2006), 98.

16. O. Soysal, Hattischer wortschatz in hethitischer Textüberlieferung [Hattian Vocabulary in Hittite Textual Tradition] (Leiden-Boston: HdO, Brill, 2004), 304, 324 ff.

17. H. G. Guterbock, "An Outline of Hittite AN.TAH.SUM Festival", Perspectives on Hittite Civilization, Selected Writings of Hans G. Guterbock (1997): 91-98. Furthermore see, S. Alp, Beitrage zur Erforschung des Hethitischen Temples: Kultanlagen im Lichte der Keilschrifttexte [Contributions to the study of Hittite Temples: Cult Systems in Light of the Cuneiform Texts] (Ankara: TTK Yayınları, 1983): $136 \mathrm{ff}$.

18. H. G. Guterbock, "Religion und Kultus des Hethiter" ["The Religion and Culture of Hittite"], Neuere Hehiterforschung, (1964): 62; J. Tischler, Hethitisches Etymologische Glossar [Hittite Etymological Glossary] (Innscbruck: Insbrucker Beitrage zur Sprachwissenschaft 20, 1977), 213; F. Ertug, "Baharın Müjdecisi: Cigdem (Crocus) ya da AN.TAH.SUM ${ }^{\text {SAR }}$ Hititler Devri Anadolu Florasına Kucuk Bir Katkı" [Harbinger of Spring: Crocus "Cigdem" or AN.TAH.SUM ${ }^{\mathrm{SAR}}$ a Small Contribution to the Anatolian Flora of the Hittite Period], Turkiye Bilimler Akademisi Arkeoloji Dergisi, 3, (2000): 129-136.

19. "anthos"; F. Cornelius, "Das Hethitische ANTAHSUM(SAR)-Fest" ["The Hittite ANTAHSUM(SAR)-Festival"], Actes de la Rencontre Assyriologique Internationale, 17 (1969): 171.

20. S. Erkut, "Hititlerde AN.TAH.SUMSAR Bitkisi ve Bayramı Uzerine Bir Inceleme" ["An Examination about AN.TAH.SUMSAR Plant and Its Festival"], III. Uluslararasl Hititoloji Kongresi Bildirileri, Corum 16-22 Eylul 1996 (1998): 194.

21. O. R. Gurney, The Hittites (Melbourne, London, Baltimore: Penguins Book, 1952), 153. H. Ertem, Bogazkoy Metinlerine Gore Hititler Devri Anadolu'sunun Florası [According to the Bogazkoy Texts the Anatolian Flora in Hittite Age] (Ankara: Turk Tarih Kurumu Basımevi, 1974), 36. "April"; Unal, Hititler Devrinde Anadolu II, 95.

22. "they open harsi pithos of the right side of the Storm-god of Zippalanda" KBo 10.20 I 38

23. "they open harsi pithos of the Storm-god of Hatti" KBo 10.20 II 15.

24. VBot 122 8; C. W. Carter, Hittite Cult-Inventories (Chicago: The Department of Oriental Languages and Civilizations, 1962), 180. KUB 38.32 6, VAT 7480+7502 Oy. 18, 20; L., Rost, "Zu den hethitischen Bildbeschreibungen (I. Teil)" ["The Hittite image descriptions (Part I)"], Mitteilungen des Institutes fur Orientforschung, 8, (1963): 172. 
hešuwaš) ${ }^{25}$ and the grains inside were used in the celebrations made during the festival. $^{26}$

Another ritual that was performed related with the AN.TAH.ŠUM Plant Festival was the hadaúri festival ( ${ }^{\mathrm{EZEN}}$ hadaúri). This festival, the lexical meaning of which is unknown, was actually a ritual where sheep were sacrificed and offered to gods on the $12^{\text {th }}, 17^{\text {th }}, 20^{\text {th }}$ and $21^{\text {st }}$ days of AN.TAH.SUM Plant Festival. ${ }^{27}$

Another Hittite festival that was celebrated in spring was the Spring Festival ( ${ }^{\text {EZEN }}$ hamešhantaš/DIŠUITES I $) .{ }^{28}$ It was claimed that the name of the festival, hamešhantaš, originated from hant-weša and hant-miyašha. ${ }^{29}$ From this point of view, hant-weša means 'spring' in Hittite language. The morpheme mai-/miya- included in the second word, as it can also be seen in texts about purulliyaš festival, means "to grow". ${ }^{30}$

Rituals to make it rain for the sake of a fertile agricultural period were common in the ancient Near East. A ritual that must have been connected with this type of practice is mentioned in the Hittite cuneiform texts. The ceremony called the Rain Festival ( ${ }^{\mathrm{EZEN}}$ heuwaš/ZŪNNI) was most probably performed in spring. ${ }^{31}$ Otherwise, the festival of procreation (?)/birth (?) ( ${ }^{\text {EZEN }}$ haššumašs $)^{32}$

25. Carter, Hittite Cult-Inventories, 181; Rost, "Zu den hethitischen Bildbeschreibungen", 172.

26. M. Popko, Kultobjecte in der Hethitischen Religion (nach keilschriftlichen Quelen) [The Cultic Material in Hittite Religion (According to Cuneiform Sources)] (Warszawa: Wydawnictwa Universytetu Warszawskiego, 1978), 84. "When it becomes spring (and) it thunders the harsi-vessel they break open"; KBo 2.7 Oy. 9; Carter, Hittite Cult-Inventories, 96. Grains in the vessel used for some rituals. KUB 25.23 I 38-50; J. Hazenbos, "Die lokalen Herbst- und Fruhlingsfeste in der spaten hethitischen Großreichszeit" ["The Local Autumn and Spring Festivals in the Late Hittite Empire]. Offizielle Religion, lokale Kulte und individuelle Religiositat. Alter Orient und Altes Testament, 318, (2004): 245. Popko, Kultobjecte in der Hethitischen Religion, 84.

27. Guterbock, "An Outline of Hittite AN.TAH.SUM Festival", 93, 94.

28. Goetze, "On the Hittite Words for 'Year' and the Seasons and for 'Night' and 'Day'", 469.

29. Hoffner, Alimenta Hethaeorum, 15.

30. KBo 3.7 I 3-8; G. Beckman, "The Anatolian Myth of Illuyanka", 18.

31. H. A. Hoffner, "An English-Hittite Dictionary", Revue Hittite et Asianique, XXV/80, 1967): 41; Rost, "Zu den hethitischen Bildbeschreibungen", 173. A Hittite text indicates that the Hittite King visited Ankuwa so as to celebrate the Rain Festival in spring: VAT 7458; H. Otten, "Ein Hethitisches Festritual (KBo XIX 128)" ["A Hittite Festival Ritual (KBo XIX 128)"], Studien zu den Bogazkoy-Texten, 13 (1971): 48; A. Unal, "Nochmals zur Geschischte und Lage Hethitischen Stadt Ankuwa" ["Once Again the History and Localization of the Ankuwa City"], Studi Micenei ed Egeo-Anatolici, 24, (1984): 103. In some areas this is an annual spring rite in today's Anatola and it is believed that the rain will continue to fall. I. Basgoz, "Rain-Making Ceremonies in Turkey and Seasonal Festivals", Journal of Amreican Orinetal Society, 87, no. 3 (1967): 304. The most precipitous period in the Central Anatolia starts in the last days of April and continues throughout May. Just as it is today, this rainy period, called Kırkikindi (Convectional) rain, was vital for Hittites, who were dependent on farming to survive. The period when the Rain Festival mentioned in Hittite texts could have been performed in parallel with that rainy period. The festival is mentioned in the $38^{\text {th }}$ day of AN.TA H.SUM Plant Festival: "the next day the king performs the Rain festival" (KBo 10.20 IV 19: Guterbock, "An Outline of Hittite AN.TAH.SUM Festival", 97). This statement shows that ${ }^{\text {EZEN }}$ heuwas is a ritual in of AN.TAH.SUM Plant Festival.

32. Unal, Multilinguales Handworterbuch des Hethitischen, 196. 


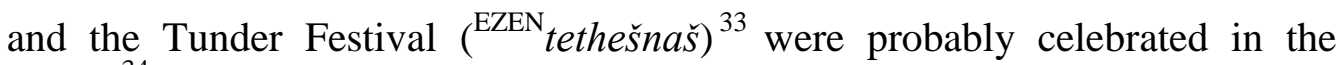
spring. ${ }^{34}$

No discrimination was made in the Hittite cuneiform texts between the seasons of spring and summer. However, there are opinions about the existence of a separate summer season. ${ }^{35}$ Just as spring refers to soil and seeds, the characteristic feature of the following season is the harvest.

One of the festivals that are thought to have been celebrated in summer was the Sickle Festival ${ }^{36}$ (EZEN URUDU ${ }^{\text {SUU.KIN.DÚ). }}{ }^{37}$ The period when the festival was celebrated must have been around June, which is also called the Sickle Month in Anatolia today. ${ }^{38}$ In Central Anatolia, crops, the seeds of which are planted in spring, are the first harvested in the month of June.

The Harvest Festival ( ${ }^{\text {EZEN }}$ U.BURU/GIS ${ }^{\mathrm{B}}$ BURU/BURU $14{ }^{39}$ ) mentioned in the Hittite texts must also have been celebrated in summer, along with the Sickle festival, because there is no evidence in the Hittite texts that crops were harvested in spring. ${ }^{40}$ There is little information about the Fruit Festival $\left({ }^{\text {EZEN }}\right.$ GURUN $\left.{ }^{41}\right)$ mentioned in the texts as well. Nevertheless, it is probable that the festival was performed in summer, when the fruits are harvested.

In accordance with the information provided in the Hittite texts, it is difficult to discriminate fall from summer, because harvesting of some crops

33. Unal, Multilinguales HandwOrterbuch des Hethitischen, 716. Hoffner, "An EnglishHittite Dictionary", 41. Rost, "Zu den hethitischen Bildbeschreibungen", 173.

34. ${ }^{\mathrm{EZEN}}$ tethesnas: KUB 25.13 I 8: Carter, Hittite Cult-Inventories, 170. For the contrary arguments see: KUB 18.12 Vs. 1-5.

35. The word BURU $U_{X}$ was used in the texts to represent summer. BURU $U_{X}$ lexically means harvesting. Thus, it is assumed to refer to harvesting period; H. A. Hoffner, Alimenta Hethaeorum, 24

36. Rost, "Zu den hethitischen Bildbeschreibungen", 173. Unal, Multilinguales HandwOrterbuch des Hethitischen, 465. "The festival of plow"; Hoffner, "An English-Hittite Dictionary", 40.

37. Carter, Hittite Cult-Inventories, 183; G. F. del Monte and J. Tischler, Die Orts und Gewassernamen der Hethitischen Texte [Name of the Location and the Rivers in the Hittite Texts] (Wiesbaden: Répertoire Géographique des Textes Cunéiformes 6, 1978), 343.

38. The Sun God ( $\left.{ }^{\mathrm{D} U T U-S I}\right)$ associated with the festival; KUB 42.91 rev. III 1-9; J. Hazenbos, The Organization of the Anatolian Local Cults during the Thirteenth Century B.C., Cuneiform Monographs 21 (Leiden, Boston: Brill, 2003), 112. KBo 2.1 I 44; Rost, "Zu den hethitischen Bildbeschreibungen", 173.

39. $\mathrm{BURU}_{14} / \mathrm{BURU}_{\mathrm{X}}$ (earlier EBUR)=harvest, harvest season/summer: A. Unal, HititceTurkce, Turkce-Hititce Buyuk Sozluk [Hittite-Turkish, Turkish-Hittite Dictionary] (Ankara: Bilgin Kültür Sanat Yayınları, 2016), 103.

40. Hoffner, Alimenta Hethaeorum, 15, 16. ${ }^{\text {EZEN }}{ }_{\text {BURU }}$ associated with the TelipinuGod; KUB 53.21 Ay. 6; V. Haas, Der Kult von Nerik, Ein Beitrag zur hethitischen Religionsgeschichte [The Cult in Nerik, A Contribution to the Hittite Religious History] (Roma: Papstliches Bibelinstitut, 1970), 61; hahrannas means harvest in Hittite and the word is only ones related with a festival; ${ }^{\text {EZEN }}$ hahrannas; Hoffner, "An English-Hittite Dictionary", 39.

41. Hoffner, "An English-Hittite Dictionary", 40. M. Darga, Karahna Sehri KultEnvanteri [The Cultic Inventar in the City of Karahna] (Istanbul: Istanbul Universitesi Edebiyat Fakultesi Yayınları, 1973), 17. F. Starke, "Untersuchung zur Stammbildung des Keilshrift-luwischen Nomens" ["Investigation to Formation of the Cuneiform Luwian Noun"], Studien zu den Bogazkoy-Texten, 31 (1990): 472. The Storm-Gos associated with the festival; KUB 42.91 II 8; Hazenbos, The Organization of the Anatolian Local Cults During the Thirteenth Century B.C., 112. 
continues into the fall season. The characteristic features of fall can be perceived as harvesting and threshing, followed by harvesting the crops. The season is speculated to have started in September ${ }^{42}$ or August ${ }^{43}$ in the Hittites era.

One of the most important festivals that the Hittites are thought to have celebrated in fall was nuntarriyašhaš Festival ( ${ }^{\text {EZEN }}$ nuntarriyašhaš). The lexical meaning of the word is Hurry/Speed/Haste Festival ${ }^{44}$ The festival, which lasted about forty-three days ${ }^{45}$ consisted of an intense cultic tour. Therefore, there are some opinions indicating that the festival got its name from these cultic tours that are performed intensively in a fast manner. ${ }^{46}$ Because of that, this festival is seen as the equivalent of AN.TAH.ŠUM Plant Festival, which was celebrated in spring, in the fall season by some. ${ }^{47}$ The agricultural season probably started with the AN.TAH.ŠUM Plant Festival and ended with the nuntarriyašhaš Festival. It was claimed that the Fall Festival ${ }^{48}$ $\left({ }^{\text {EZEN }}\right.$ zenandaš $^{49}$, getting its name from the season it was celebrated in, was actually the same event with nuntarriyašhaš Festival, and two different names were given to the same festival. ${ }^{50}$ Though this claim cannot be verified, it is clearly indicated in the inscriptions that the harši pithos opened in spring were filled in and sealed in the Fall Festival. ${ }^{51}$ It may be acceptable to see this event as the end of the agricultural season.

Another important event in the Hittite cultic calendar was ${ }^{\text {EZEN }}$ KI.LAM. It is generally translated as the Gate/Marketplace Festival. ${ }^{52}$ The festival lasted

42. Gurney, The Hittites, 152.

43. Hoffner, Alimenta Hethaeorum, 13.

44. CHD, Vol. L-N, (Chicago: Oriental Institute, 1989), 473; Unal, Multilinguales Handworterbuch des Hethitischen, 494; A. Goetze, Kleinasien [Asia Minor] (München: Handbuch der Altertumswissenschaft, Kulturgescihte des Alten Orients, 1957), 165; H. G. Guterbock, "Some Aspect of Hittite Festivals", Perspectives on Hittite Civilization, Selected Writings of Hans G. Guterbock, (1997), 89.

45. M. Nakamura, Das hethitische nuntarriyasha-Fest [The Hittite nuntarriyashaFestival] (Leiden: Nederlands Instituut voor het Nabije Oosten, 2002), 139.

46. J. Friedrich, "Alte und neue hethitische WOrter" ["New and Old Hittite Words"], Archiv Orientalni, 6 (1934), 373. For detailed information about cult journeys see: Gavaz, Hitit Krallarının Kult Gezileri.

47. Friedrich, "Alte und neue hethitische WOrter", 407.

48. Goetze, "On the Hittite Words for 'Year' and the Seasons and for 'Night' and 'Day"', 467; Unal, Multilinguales Handworterbuch des Hethitischen, 818. Rost, "Zu den hethitischen Bildbeschreibungen", 173.

49. Goetze, "On the Hittite Words for 'Year' and the Seasons and for 'Night' and 'Day'", 469. Darga, Karahna Sehri Kült-Envanteri, 14. Suel, Hitit Kaynaklarında Tapınak Gorevlileri ile Ilgili Bir Direktif Metni, 27, 49.

50. Guterbock, "Some Aspect of Hittite Festivals", 88

51. Hazenbos, "Die lokalen Herbst- und Frühlingsfeste in der späten hethitischen Großreichszeit", 242, 243. Carter, Hittite Cult-Inventories, 180,181. Rost, "Zu den hethitischen Bildbeschreibungen", 172.

52. KI.LAM="market place"; Hoffner, "An English-Hittite Dictionary", 40, 56. A. Unal, Multilinguales HandwOrterbuch des Hethitischen, s. 340. The name of festival is uncertain.

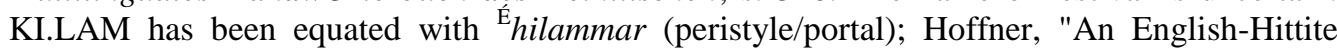
Dictionary", 40. T. van den Hout, "Some Remarks on the Third Tablet of the Hittite KI.LAM Festival," Jaarbericht van het Vooraziatisch-Egyptisch Genootschap, 32 (1993): 102. 
just for three days and the libations were made for the sake of Crops God ( ${ }^{\mathrm{D}}$ alki). ${ }^{53}$ Royal depot keepers coming from different cities stood next to piles of crops they brought, and presented their "houses" in turn and performed their libations ${ }^{54}$ after they were introduced to the king in the order of the names of cities. The meaning of "houses" is unclear in this context, yet it is possible that it is related with the pile of crops mentioned in the previous sentence. In this sense, it can be stated that agricultural products coming from different cities were presented to the king and this event was actually some sort of a taxation ceremony. The festival could have taken its name from the venue of the event, as it might have been performed at the gate or in the garden of the palace. The fact that the festival was performed at a time when agricultural yield was very high during the harvesting period, ${ }^{55}$ the city depots were full and a certain amount of crops were brought to the capital supports this very idea.

Another festival related with harvesting was the Vintage/Grape Harvest

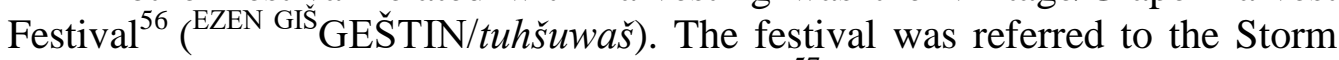
God, who represents harvesting in mythology. ${ }^{57}$ Even if we cannot indicate an exact date for the Hittites era, presently, grapes are generally harvested on the first days of September in Anatolia.

There are also some festivals mentioned in the cuneiform texts of the Hittites about threshing performed upon harvesting. These festivals are called Threshing Floor/Accumulating Festival ${ }^{58}$ ( ${ }^{\text {EZEN }}$ hahrannaš), Grain/Crop Piling/Compile of Grain Festival ${ }^{59}$ ( ${ }^{\mathrm{EZEN}}$ harpaš/harpiya), and Cereal

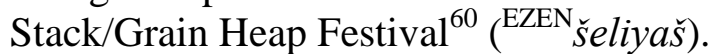

After fall, in parallel with the end of the agricultural season, there were almost no festivals celebrated in winter. ${ }^{61}$ The most prominent festival

53. KBo 10.24 IV 19-20; I. Singer, "The Hittite KI.LAM Festival, Part Two", Studien zu den Bogazkoy-Texten, 28, (1984): 127.

54. KUB 10.1 I 1-28; Singer, "The Hittite KI.LAM Festival, Part Two", 22-23.

55. Singer, "The Hittite KI.LAM Festival, Part Two", 133. There may be a connection between KI.LAM and nuntarriyashas. KI.LAM is three-day event in the festival of nuntarriyashas. T. Bryce, Hitit Dunyasında Yaşam ve Toplum [The Life and Society in the Hittite World] (Ankara: Dost Kitabevi, 2003), 211, 212; T. van den Hout, "Some Remarks on the Third Tablet of the Hittite KI.LAM Festival", 102; C. Conti, "Notes Regarding Days 12, 13 and 14 of the nuntarriyashas Festival According to the Second Outline Source", Tabularia Hethaeorum, Hethitologische Beiträge Silvin Kosak zum 65. Geburtstag, Dresdner Beiträge zur Hethitologie 25 (2007): 174.

56. Hoffner, "An English-Hittite Dictionary", 40; Unal, Multilinguales Handworterbuch des Hethitischen, 731.

57. KUB 42.91 III 10; Hazenbos, The Organization of the Anatolian Local Cults During the Thirteenth Century B.C., 112. KUB 38.12 I 23; Rost, "Zu den hethitischen Bildbeschreibungen", 172.

58. Unal, Multilinguales HandwOrterbuch des Hethitischen, 143. Hoffner, "An EnglishHittite Dictionary", 39. hahrannas is derived from hahratar/haharattar/hahrannat and one of its meanings is threshing floor. H. G. Guterbock, "Some Aspect of Hittite Festivals", 88. The festival must be celebrated after harvest. in August or September.

59. Hoffner, "An English-Hittite Dictionary", 39.

60 . Hoffner, "An English-Hittite Dictionary", 40; Rost, "Zu den hethitischen Bildbeschreibungen", 173; Darga, Karahna Sehri Kült-Envanteri, 14.

61. According to Hoffner the harvest continued from July to October and the winter began in November. Hoffner, Alimenta Hethaeorum, 28. 
mentioned in the Hittite texts is the Winter Festival ( ${ }^{\text {EZEN }}$ gimmant), which got its name from the season it was performed in. ${ }^{62}$ Otherwise, ${ }^{\text {EZEN }}$ MU-ti was probably celebrated in the winter.

It is observed that most of the festivals mentioned in the cuneiform texts of the Hittites were closely related with the agricultural season throughout the year. Rituals starting in spring and aiming at maintaining a fertile agricultural season, ended with rituals about harvesting and threshing performed in summer and fall. As per this fact, we can interpret that the spiritual world of Hittites was immensely influenced by such an economic activity as agriculture. ${ }^{63}$

Table 1. Distribution some of the Hittite Festivals Related with Agricultural Cycle According to the Seasons

\begin{tabular}{|c|c|c|}
\hline Season & Festival Name & Trans. of Festival Names \\
\hline \multirow{5}{*}{ 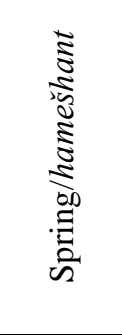 } & EZEN purulli/wurulli/ purulliyaš & f. of earth \\
\hline & ${ }_{\text {EZEN }}$ AN.TAH.ŠUM ${ }^{\text {SAR }}$ & f. of AN.TAH.ŠUM plant \\
\hline & EZEN DUG harši hešuwaš & f. of openning the harši vessel \\
\hline & ${ }_{\text {EZEN }}^{\text {hamešhanda/DIŠU/TEŠI }}$ & f. of spring \\
\hline & ${ }^{\mathrm{EZEN}}$ hewaš/ZU-UN-NI & f. of rain \\
\hline \multirow{3}{*}{ 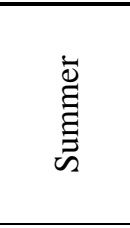 } & EZENŠU.KIN.DÚ//RUDU ŠU.KIN.DÚ & $\begin{array}{l}\text { festival of wielding the sickle, of } \\
\text { sickle }\end{array}$ \\
\hline & EZEN Ú.BURU/ GIŠ BURU/ EBUR & f. of harvest \\
\hline & ${ }^{\text {EZEN }}$ GURUN & f. of fruit \\
\hline \multirow{8}{*}{ 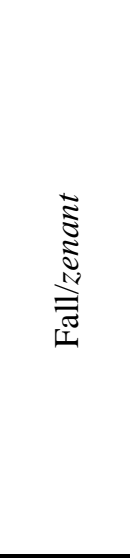 } & ${ }_{\text {EZEN }}^{\text {nuntarriyašhaš }}$ & f. of haste, of swiftness \\
\hline & $\mathrm{EZEN}_{\text {zenandaš }}$ & f. of fall \\
\hline & ${ }^{\text {EZEN } h a r s ̌ i ~ s ̌ s u h h u w a s ̌ ~}$ & f. of pouring into harši vessel \\
\hline & ${ }^{\text {EZEN }}$ KI.LAM & f. of gate, of marketplace \\
\hline & EZEN.GIŠGEŠTIN/ tuhšuwaš & f. of grape harvest \\
\hline & ${ }^{\mathrm{EZEN}}$ hahrannaš & $\begin{array}{l}\text { f. of accumulating, ingahtering (of } \\
\text { crops) }\end{array}$ \\
\hline & ${ }^{\text {EZEN }}$ harpaš/harpiya & f. of compile of grain \\
\hline & EZEN $_{\text {šeliyaš }}$ & f. of grain heap \\
\hline $\begin{array}{l}\text { Winter/ } \\
\text { gimant }\end{array}$ & ${ }^{\mathrm{EZEN}_{\text {gimmant }}}$ & f. of winter \\
\hline
\end{tabular}

62. Goetze, Kleinasien, 468.

63. Ardzinba, Eskicag Anadolu Ayinleri ve Mitleri, $13 \mathrm{ff}$. 
Bibliography

Alp, S. Beitrage zur Erforschung des Hethitischen Temples: Kultanlagen im Lichte der Keilschrifttexte [Contributions to the study of Hittite Temples: Cult Systems in Light of the Cuneiform Texts]. Ankara: TTK Yayınları, 1983.

Archi, A. A. "Das Kultmahl bei den Hethitern" ["The Cultic-Meal in the Hittites"]. 8 TUrk Tarih Kongresi, TTK Yayınları, (1979): 197-213.

Ardzinba, V. Eskicag Anadolu Ayinleri ve Mitleri [The Anatolian Rituals and Myths in the Ancient Age]. Ankara: Kafdav Y., 2010.

Basgoz I., "Rain-Making Ceremonies in Turkey and Seasonal Festivals." Journal of Amreican Orinetal Society, 87, no. 3, (1967): 304.

Beckman, G. "The Anatolian Myth of Illuyanka". Journal of Near Eastern Studies, 14, (1982): 11-25.

Bryce, T. Hitit DUnyasında Yaşam ve Toplum [The Life and Society in the Hittite World]. Ankara: Dost Kitabevi, 2003.

Carter, C. W. Hittite Cult-Inventories. Chicago: The Department of Oriental Languages and Civilizations, 1962.

Chicago Hittite Dictionary, Volume L-N (CHD, Vol. L-N). Chicago: Oriental Institute, 1989.

Chicago Hittite Dictionary Volume P. (CHD, Vol. P.). Chicago: Oriental Institute, 1997.

Conti, C. "Notes Regarding Days 12, 13 and 14 of the nuntarriyašhaš Festival According to the Second Outline Source". Tabularia Hethaeorum, Hethitologische Beiträge Silvin Košak zum 65. Geburtstag, Dresdner Beiträge zur Hethitologie 25 (2007): 163-174.

Cornelius, F. "Das Hethitische ANTAHSUM(SAR)-Fest" ["The Hittite ANTAHSUM (SAR)-Festival"]. Actes de la Rencontre Assyriologique Internationale, 17 (1969): 171-174.

Darga, M. Karahna Sehri Kult-Envanteri [The Cultic Inventar in the City of Karahna]. Istanbul: Istanbul Universitesi Edebiyat FakUltesi Yayınları, 1973.

del Monte, G. F. and Tischler, J. Die Orts und Gewassernamen der Hethitischen Texte [Name of the Location and the Rivers in the Hittite Texts]. Wiesbaden, Répertoire Géographique des Textes Cunéiformes 6, 1978.

Erginoz, G. S. "Hititlerde Astronomi Bilgisine ve Hitit Takvimine Bir Bakıs" ["An essay on the astronomical knowledge and the calendar of the Hittites"]. Osmanl Bilimi Araştırmaları, 9, no 1-2 (2008): 199-213.

Erkut, S. "Hititlerde AN.TAH.SUMSAR Bitkisi ve Bayramı Uzerine Bir İnceleme" ["An Examination about AN.TAH.SUMSAR Plant and Its Festival"]. III. Uluslararası Hititoloji Kongresi Bildirileri, Corum 16-22 Eylul 1996 (1998): 189-195.

Ertem, H. Bogazkoy Metinlerine Göre Hititler Devri Anadolu'sunun Florası [According to the Bogazkoy Texts the Anatolian Flora in Hittite Age]. Ankara: Turk Tarih Kurumu Basımevi, 1974.

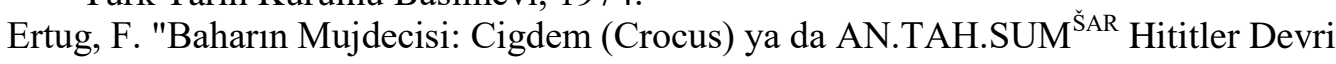
Anadolu Florasına KUcUk Bir Katkı" [Harbinger of Spring: Crocus "Cigdem" or AN.TAH.SUM ${ }^{\text {S̆AR }}$ a Small Contribution to the Anatolian Flora of the Hittite Period]. Turkiye Bilimler Akademisi Arkeoloji Dergisi, 3, (2000): 129-136.

Friedrich, J. "Alte und neue hethitische Worter" ["New and Old Hittite Words"]. Archiv Orientalni, 6, (1934): 358-376. 
Gavaz, O. S. Hitit Krallarının Kult Gezileri. Ayinler, Ziyaret Merkezleri, Yollar, Lokalizasyonla Ilgili Yeni Gozlemler [The Cultic-tour of Hittite Kings, Rituals, Visiting Centers, Roads, New Observation about the Localizations]. Corum: Corum Belediyesi Yayınları, 2012.

Goetze, A. "Die Annalen des Mursilis" ["The Annals of Mursilis II"]. Mitteilungen der Vorderasiatisch, Aegyptischen Gesellschaft, 38, 1933.

Goetze, A. "On the Hittite Words for 'Year' and the Seasons and for 'Night' and 'Day'". Language, 27, no 4 (1951): 467-476.

Goetze, A. Kleinasien [Asia Minor]. Munchen: Handbuch der Altertumswissenschaft, Kulturgescihte des Alten Orients, 1957.

Grayson, A. K. "Chronicles and the Akitu Festival". Rencontre Assyriologique Internationale, 17 (1970): 160-170.

Gurney, O. R. The Hittites. Melbourne, London, Baltimore: Penguins Book, 1952.

Guterbock, H. G. "The Hittite Version of the Hurrian Kumarbi Myths: Oriental Forerunners of Hesiod, Plate III". American Journal of Arhaeology, 52, no 1 (1948): 123-134.

Guterbock, H. G. "Religion und Kultus des Hethiter" ["The Religion and Culture of Hittite"]. Neuere Hehiterforschung, (1964): 54-73.

Guterbock, H. G. "An Outline of Hittite AN.TAH.SUM Festival". Perspectives on Hittite Civilization, Selected Writings of Hans G. Guterbock, (1997): 91-98

Guterbock, H. G. "Some Aspect of Hittite Festivals". Perspectives on Hittite Civilization, Selected Writings of Hans G. GUterbock, (1997): 87-90.

Haas, V. Der Kult von Nerik, Ein Beitrag zur hethitischen Religionsgeschichte [The Cult in Nerik, A Contribution to the Hittite Religious History]. Roma: Päpstliches Bibelinstitut, 1970.

Haas, V. "Geschichte der Hethitischen Religion." Handbuch der Orientalistik, 15, 1994.

Haas, V. Die Hethitische Literatur: Texte, Stilistik, Motive [The Hittite Literature: Texts, Style, Motives]. Berlin: DEU: Walter de Gruyter, 2006.

Hazenbos, J. The Organization of the Anatolian Local Cults During the Thirteenth Century B.C.. Cuneiform Monographs 21, Leiden, Boston: Brill, 2003.

Hazenbos, J. "Die lokalen Herbst- und FrUhlingsfeste in der späten hethitischen Großreichszeit" [The Local Autumn and Spring Festivals in the Late Hittite Empire]. Offizielle Religion, lokale Kulte und individuelle Religiosität. Alter Orient und Altes Testament, 318 (2004): 241-248.

Hoffner, H. A. "An English-Hittite Dictionary". Revue Hittite et Asianique, 25, no. 80 (1967): 1-99.

Hoffner, H. A. Alimenta Hethaeorum [Food Production in Hittite Asia Minor]. New Heaven: American Oriental Series 55, 1974.

Hoffner, H. A. The Laws of the Hittites: a Critical Edition. Leiden, New York, Köln: Documenta et Monumenta Orientis Antiqui, 1997.

Koch-Westenholz, U. "Mesopotamian Astrology at Hattusa." Grazer Morgenlandische Studien, 3, Die Rolle der Astronomie in den Kulturen Mesopotamiens. Beiträge zum 3. Grazer Morgenländischen Symposium, 23-27. September 1991, (1993): 231-246.

Nakamura, M. Das hethitische nuntarriyasha-Fest [The Hittite nuntarriyashaFestival]. Leiden: Nederlands Instituut voor het Nabije Oosten, 2002.

Otten, H. "Ein Hethitisches Festritual (KBo XIX 128)" ["A Hittite Festival Ritual (KBo XIX 128)"] Studien zu den Bogazköy-Texten, 13, (1971).

Okse, A. T. "Eski Önasya'dan Gunumuze Yeni Yıl Bayramları, Bereket ve Yagmur Yagdırma Törenleri" ["New Year Feasts, Fertility and Rain Making Ceremonies 
since the Early Near East"]. Bilig, Ahmet Yesevi Universitesi Sosyal Bilimler Dergisi, 36, (2006): 47-68.

Popko, M. Kultobjecte in der Hethitischen Religion (nach keilschriftlichen Quelen) [The Cultic Material in Hittite Religion (According to Cuneiform Sources)]. Warszawa: Wydawnictwa Universytetu Warszawskiego, 1978.

Rochberg, F. "Astronomy and Calendars in Ancient Mesopotamia." Civilizations of the Ancient Near East, 3 (2000): 1925-1940.

Rost, L. "Zu den hethitischen Bildbeschreibungen (I. Teil)" ["The Hittite image descriptions (Part I)"]. Mitteilungen des Institutes fur Orientforschung, 8 (1963): 161-217.

Say1l, A. Misirlılarda ve Mezopotamyalılarda Matematik, Astronomi ve Tip [Mathematics, Astronomy and Medicine in the Egyptians and Mesopotamians] Ankara: TUrk Tarih Kurumu Basımevi, 1966.

Singer, I. "The Hittite KI.LAM Festival, Part Two", Studien zu den Bogazkoy-Texten, 28, (1984).

Starke, F. "Untersuchung zur Stammbildung des Keilshrift-luwischen Nomens" ["Investigation to Formation of the Cuneiform Luwian Noun"]. Studien zu den Bogazköy-Texten, 31, (1990).

Suel, A. Hitit Kaynaklarında Tapınak Gorevlileri ile Ilgili Bir Direktif Metni [An Instruction Text about the Temple Officiers in the Hittite Sources]. Ankara, Ankara Universitesi Dil ve Tarih Cografya Fakultesi Yayınları, 1985.

Soysal, O. Hattischer wortschatz in hethitischer TextUberlieferung [Hattian Vocabulary in Hittite Textual Tradition]. Leiden-Boston: HdO, Brill, 2004.

Tischler, J. Hethitisches Etymologische Glossar [Hittite Etymological Glossary]. Innscbruck: Insbrucker Beitrage zur Sprachwissenschaft, Band 20, 1977.

Unal, A. "Nochmals zur Geschischte und Lage Hethitischen Stadt Ankuwa" ["Once Again the History and Localization of the Ankuwa City"]. Studi Micenei ed Egeo-Anatolici, 24, (1984): 87-107.

Unal, A. The Hittite Ritual of Hantitau from the City of Hurma against Troublesome Years. Ankara: TTK Yayınları, 1996.

Unal, A. Hititler Devrinde Anadolu II [Anatolia in Hittite Age II]. Istanbul: Arkeoloji ve Sanat, 2003.

Unal, A. Multilinguales Handworterbuch des Hethitischen [A Concise Multilingual Hittite Dictionary] Hitit Cok Dilli El Sozlugu. Hamburg: Verlag Dr. Kovac, Fachverlag fur Wissenschaftliche Literatur, 2007.

Unal A. Hititce-Turkce, TUrkce-Hititce Buyuk Sozluk [Hittite-Turkish, Turkish-Hittite Dictionary]. Ankara: Bilgin Kultur Sanat Yayınları, 2016.

van den Hout, T. "Some Remarks on the Third Tablet of the Hittite KI.LAM Festival." Jaarbericht van het Vooraziatisch-Egyptisch Genootschap, 32, (1993): 101-118.

Walcot, P. Hesiod and the Near East. Cardiff: Wales U.P., 1966. 